\title{
Judicial Cosmopolitan Authority
}

\author{
Claudio Corradetti \\ Faculty of Law, University of Oslo, Norway*
}

In the following article, I reconstruct the conditions of validity for claims of cosmopolitan authority and their corresponding judicial practices. I maintain that the authority of the law articulates the structure of a cosmopolitan constitution, overlapping at both the domestic and the international legal domain. It is worth noting that, whereas in the domestic sphere claims to both cosmopolitan and not cosmopolitan legitimate authority, are embedded within a preformed constituted unity of the law (constitution), in the transnational they perform a constituting function for legal integration (constitutionalism). Within the latter, pluralism remains unbound and the unity of international law turns into an interpretive task - one measured on the best account for the unity of international law. I consider, accordingly, that international law cannot be upheld by either surrendering to an idea of legal fragmentation characterized by irreconcilable conflicts among regimes, nor by a mere acceptance of an unmediated constitutional hierarchy. Here there seems to hold, instead, a partial overlapping between the two spheres, one which defines a basic structure between the domestic and the transnational. This common concern between the two jurisdictions is what gets articulated by the exercise of cosmopolitan authority.

Keywords: authority, courts, cosmopolitan law, human rights, global constitutionalism, pluralism

\section{Introduction}

"I am a citizen of the world" replied Diogenes the Cynic when questioned about his place of provenance. ${ }^{1}$ The cosmopolitan ideal has charmed western philosophy since its inception. Both the Cynics and the Stoics believed in the primacy of global affiliations as expressions of ethical virtue and human brotherhood. For Seneca there were two communities: "the one, which is great and truly common, embracing gods and men; the other, that which we have been assigned by the accident of our birth". ${ }^{2}$ How to reconcile the divide? Were the cosmopolitan order to take complete

\footnotetext{
*Email: Claudio.Corradetti@jus.uio.no. This paper was originally prepared for the conference on "Debating 'Transitional Cosmopolitanism' through the Courts" held on 3-4 March 2014 under the auspices of MultiRights, European Research Council Advanced Grant \#269841 at the University of Oslo, Norway. Among the many people that have contributed with comments I thank in particular N.Roughan, M.Saul, A.Føllesdal, G.Ulfstein, P.Capps, L.Pasquet, D.Augenstein, F.Zaumseil. I'm greatful to M.Kumm both for suggestions and for my research visit at the Rule of Law Center, Wissenchaftszentrum für Sozialforschung (WZB), in Berlin as visiting research fellow. Last but not least I thank the two anonymous reviewers for comments and suggestions. This study was possible thanks to the "Internationalization grant" I received from the Department of Public and International Law, Faculty of Law, at the University of Oslo. Eventually, all errors are mine.

${ }^{1}$ Diogenes the Cynic, in Diogenes Laertius, Lives of the Philosophers, Robert D. Hicks (trans), (Harvard University Press, 1970) VI.63.

${ }^{2}$ Seneca De otio, trans. by Anthony A. Long and David N. Sedley (eds), The Hellenistic Philosophers, (Cambridge University Press, 1987) 4.1, 67 K.
} 
preeminence, it would wipe away all different laws as well as provide a uniform standard for fellow human beings. In the long term, it would also favor the creation of a single world state as a source of law. It is not clear whether the Stoics had envisioned this option as, for instance, with Zeno's ideal city, but one can certainly draw a conceptual distinction between the scope of application and the source of validity of cosmopolitan law as with domestic and international institutions establishing — together — conditions of equal worthiness. ${ }^{3}$

Historically, the asymmetry between the universal validity of cosmopolitan law and the dispersed singularity of its institutional counterpart is what I believe had informed also the Kantian project of the Perpetual Peace [1795]. Kant's cosmopolitanism, indeed, excludes the opportunity of a domestic analogy for the structuring of the transnational domain and therefore it does not resort to a constitutional model conceived in analogy with a domestic one. ${ }^{4}$

My view cuts across the confrontation between statists and globalists since it rejects both. I consider, instead, that cosmopolitan authority advances claims of justice with regards to a basic structure, concerned with the individual, as a shared area between the domestic and the global/cosmopolitan domain. ${ }^{5}$ I depart, here, from Rawls' definition of the basic structure which he applies only to a society's major political institutions. The view I defend considers, instead, that general concerns of constitutional law as an instrument to regulate claims of justice are primarily directed to individuals and to their interactions.

Indeed the assumption is that in so far as cosmopolitan claims of public authority are concerned, at either the domestic or the international level, the individual represents a primary object of concern. In either case, there holds no fixed hierarchical order between institutions advancing such claims so that the legitimacy of action held by each public authority is gained in the absence of a single institutional guarantor of international order. This feature motivates the elaboration of legitimate rules of power-transferring through different institutional actors and legal domains, from the state to supranational organizations.

There is here an important point to be noted with regard to the transferring of judicial powers between domestic and transnational constitutionalism. This concerns the way in which adjudicative bodies assert the ultimacy of their authority. At the domestic level such ultimacy is preassigned by procedural clauses of the constitution. This can be either codified or non-codified and

\footnotetext{
${ }^{3}$ See Martha C. Nussbaum, 'Kant and Stoic Cosmopolitanism' (1997) 5 (1) The Journal of Political Philosophy 1, 6.

${ }^{4}$ For "transnational" and its connection to pluralism, I follow here the definition of Peer Zumbansen for which "the term transnational is meant [... ] to identify a methodological space in which to make sense of the conditions that shape references to law or non-law in functionally highly differentiated contexts", accepting therefore the author's move forward from the classical definition of Philip Jessup. In Peer Zumbansen 'Transnational Legal Pluralism' (2010) Research Paper No. 1/2010, Comparative Research in Law \& Political Economy, http://digitalcommons.sgoode.yorku.ca/clpe/70, 9 (accessed 14 November 2015).

${ }^{5}$ See John Rawls, A Theory of Justice (Harvard University Press, 1999, rev.ed.) §2.
} 
its legitimacy is traceable to the sovereign will of a constituent power — the people. The same does not hold for cosmopolitan constitutionalism. Here there is not a predefined allocation of powercompetences. These are rather gained through judicial argumentations and in the absence of a preset hierarchy of competences.

I want to illustrate this crucial difference with two examples. In Marbury $v$. Madison the American Supreme Court gained powers of judicial review through a constitutional struggle against the legislative. ${ }^{6}$ Yet, whereas this constitutional battle between the judicial and the legislative power was expected to be resolved within the federal constitutional framework, such that the Supreme Court could presume that it had such power, in the case of the Court of Justice of the European Union (CJEU, formerly the European Court of Justice, ECJ), the supremacy of EU law has been affirmed notwithstanding the absence of an already available constitutional framework, either codified or uncodified. Exercise of legitimate authority in these two instances originated from opposing presumptions: in the first case, from the consideration that a claim to ultimate authority is constitutionally regulated by a hierarchical system of constitutional norms (such that any competitions among powers are rather pathologies of the system); in the second case from the idea that judicial authority is to be justified against a plurality of legal constitutional orders each advancing a prima facie legitimate claim to authority. In the latter case there is no guarantee that legitimate authority should remain within the domestic realm. Whereas both at the domestic and at the transnational cosmopolitan authority advance an ultimate claim, in the first case ultimacy occurs in a hierarchical ordering whereas in the second it occurs in a heterarchical setting. ${ }^{7}$

Transnational claims to legitimate authority are not only made in the absence of a sovereign will of a constituent people but also in the absence of pre-set horizontal legitimacy checks by other powers sharing the same constitutional umbrella (the legislative, the judicial and the executive power). Legitimacy problems relative to claims of authority differ therefore quite importantly whether it is the case that either a domestic non cosmopolitan or a transnational cosmopolitan authority is at stake. The result is that the domestic analogy is not applicable in its completeness but only as a partial overlapping. ${ }^{8}$ In the absence of a pre-set definition of constitutional powers, it follows that each transnational institution, either adjudicative or executive, can advance a claim to cosmopolitan authority on the base of engagement into practical reasoning.

\footnotetext{
${ }^{6}$ Marbury v. Madison, 5 U.S. 137, 1803. See also Daniel Halberstam, 'Constitutional Heterarchy: the Centrality of Conflict in the European Union and the United States' in Jeffrey L.Dunoff and Joel P.Trachtman (eds), Ruling the World? Constitutionalism, International Law, and Global Governance (Cambridge University Press 2009$) 334 \mathrm{ff}$.

${ }^{7}$ On the role of heterarchy in federal constitutionalism see Halberstam (n 6) 326-355. Even though I recognize that global constitutionalism mirrors the federalist model, it allows for a wider independence and exclusiveness of authority.

${ }^{8}$ On the cosmopolitan character of domestic constitutional law see the contribution by P.Glenn in this symposium.
} 
These are the conceptual axes along which I pursue my argument on cosmopolitan authority and on the unity of international law. As they stand, such unity is to be understood from within a framework of constitutional pluralism where claims to cosmopolitan authority are justified on the base of substantive justifications. ${ }^{9}$ Indeed, to make a legitimate claim to cosmopolitan authority is to advance, counterfactually, an idea for the unity of international law. This is also to provide reasons in support of a "cosmopolitan turn" of constitutional theory - to paraphrase and reinforce a recent thesis by Kumm - ${ }^{10}$ as well as for proposing an account of global constitutionalism which looks more closely into the direction of a plurality of cosmopolitan authority as the defining feature of constitutionalism.

To begin with, I introduce the Razian paradox between autonomy and authority in order to account for the normativity of the law. I defend a view for which the solution of the paradox depends on the recognition of a cosmopolitan right to critique which unfolds into the judicial exercise of authority. I illustrate next how such a normative standard has been incorporated by particular case-laws. I consider, therefore, how the construction of a legitimate transferring of power-authority is reflected in some of the instances of a cosmopolitan rationale.

In order to clarify this point I focus on the legitimate transferring of cosmopolitan authority between: a) a constitutional state and the European Union, as with the German Constitutional Court in its battle for the affirmation of human rights principles for the EU; b) the claim to cosmopolitan authority against the Security Council by a quasi-federal organization as the European Union (EU) through its Court (CJEU); as well as c) the claim of cosmopolitan authority against the UN Security Council by the European Convention of Human Rights (ECtHR).

I analyze both the judicial reasoning of the CJEU and the ECtHR with regard to the recent UN Security Council Resolution 1267 on the "terror list" originally adopted in 1999 and later extended with Resolution 1390 (2002). I maintain that each judicial regime, while complying with

\footnotetext{
${ }^{9}$ Following Doyle's understanding the only way to accommodate the constitutional reading of the UN Charter with my notion of constitutional pluralism is by recognizing that the UN Charter represents a constitution sui generis in so far as it shows only one of three properties of a state constitution. Indeed, while the UN Charter embeds the property of supremacy, it does not ground per se the unity of neither international law nor it provides "the legal source of all international law", see Michael Doyle, 'The UN Charter - a Global Constitution?' in Jeffrey L.Dunoff and Joel P.Trachtman (eds), Ruling the World? Constitutionalism, International Law, and Global Governance (Cambridge University Press 2009) 114. On a different definition of pluralism compatible with the notion of pluralism presented here, see Miguel Poiares Maduro, 'Courts and Pluralism: Essay on a Theory of Judicial Adjudication in the Context of Legal and Constitutional Pluralism' in Jeffrey L.Dunoff and Joel P.Trachtman (eds), Ruling the World? Constitutionalism, International Law, and Global Governance (Cambridge University Press 2009) 356-7. The question is whether and to what extend Poiares Maduro is advancing a standard form of pluralism and not, instead, a global constitutionally mitigated one.

${ }^{10}$ Mattias Kumm, 'The Cosmopolitan Turn in Constitutionalism: An Integrated Conception of Public Law' (2013) 20 Indiana Journal of Global Studies, 605-628. On the "framing" function of cosmopolitanism see Neil Walker 'Taking Constitutionalism beyond the State' (2008) 56 Political Studies 519, 519-543 and in particular, 525.
} 
its own standards, has succeeded in providing an interpretation of human rights by presupposing counterfactually an ideal unity for international law.

In the final section, I integrate the central features of cosmopolitan authority with two other judicial mechanisms, that is, with judicial dialogue and the transitional justice adjudications of the ECHR. In each of these instances I detect both systemic incorporations of cosmopolitan standards as well as the fulfillment of minimum democratic thresholds. ${ }^{11}$

\section{\$1 Conceptualizing Cosmopolitan Authority}

In this section, I conceptualize the normative determinants of cosmopolitan authority. Whereas political authority in general has been often defined as either a claim to power, a right to rule, an expertise or an epistemic competence, I consider that authority is best defined as the duty to provide a justification. More extensively, it can be defined as an illocutive speech act advancing a pretense of coordination on the basis of a justified obligation. ${ }^{12}$ This pretense, in its general form, is constructed as an obligation from a second-person perspective to explain the rational grounds upon which a measure is adopted. Starting from the assumption of a priority of autonomy over authority, it follows that any restriction or modification of the reasons that apply to one's freedom to selfdetermination should comply with a general standard of public justification. I therefore reinterpret Forst's right to justification in terms of a duty to provide a reasonable limitation to our innate right to freedom. ${ }^{13}$

My argument proceeds in the following way: I begin with Raz's puzzle of the paradox of authority for which there is a supposed incompatibility between autonomy and authority; I then suggest how the overcoming of the paradox depends upon the recognition of a cosmopolitan duty of justification which applies to the exercise of public authority.

The thesis I defend here also requires addressing the following questions:

a) On what normative grounds is the notion of cosmopolitan authority justified?

b) How does cosmopolitan authority provide a standard for a legitimate exercise of power in a condition of pluralism?

\footnotetext{
${ }^{11}$ On this point see also the contribution by A.Føllesdal in this symposium.

${ }^{12}$ On the relation between illocutive statements and weak natural law theory see Mark Murphy, Natural Law in Jurisprudence and Politics (Cambridge University Press, 2009). On one of the most successful criticisms of Raz's theory of authority see Stephen Darwall, 'Authority and Reasons: Exclusionary and Second-Personal', (2010) 120 (2) Ethics, 257-278.

${ }^{13}$ Rainer Forst, The Right to Justification. Elements of a Constructivist Theory of Justice (Columbia University Press, New York, 2014).
} 
c) How does cosmopolitan authority impact upon transnational constitutionalism?

How do claims to cosmopolitan authority contribute to the construction of a "cosmopolitan condition" and overcome the threat of legal fragmentation?

According to Raz's formulations, the paradox of autonomy and authority subscribes to the following statement: "To be subjected to authority [...] is incompatible with reason, for reason requires that one should always act on the balance of reasons of which one is aware". ${ }^{14}$ If we agree with Raz in defining autonomy as a power to act in accordance with the reasons that are given to oneself and authority as a normative power to change those reasons that apply to others, ${ }^{15}$ then the cosmopolitan duty to provide a justification is the obligation of authority to advance reasons that apply to others in virtue of a process of generalization of those same reasons that apply to oneself. I will break this formulation into steps.

According to Raz's service conception, claims to authority are legitimate in so far as they perform a service; that is, in so far as they deliver the reasons that apply to us. ${ }^{16}$ As Raz asserts, one can distinguish between two aspects: one theoretical and the other practical. Authority, in its theoretical dimension, raises the question of how to understand an authoritative directive. Simply put, the question is: who can legitimately exercise the right to rule? How can one person's claim represent a duty for another? Here the argument that is made draws from the analogy with promising. The demands of legitimate authority, from a theoretical perspective, assert that when we promise something we impose on ourselves an obligation; similarly, with authority we impose duties on others that they did not have before. ${ }^{17}$ There are conditions which apply to promises: the promisor must know the meaning of his promise, such as that the act promised must not be immoral, etc., and this is what makes a promise valid and binding. Given these standards of legitimacy, a person has authority over another only if there are sufficient reasons for the other to be subject to the duties imposed by the former. The theoretical problem does not solve the conundrum over authority, and the moral requirement also applies.

The question to be answered is the following: how can it be that one has a duty to subject one's will to the judgment and the will of another? For authority, it is not just subordination, but rather subordination in accordance to a reason that is binding. For the service conception, however, this necessitates that two other requirements be met. These are what Raz defines as:

\footnotetext{
${ }^{14}$ Josef Raz, The Authority of Law (Oxford University Press, 2009) 3.

${ }^{15} \operatorname{Raz}$ (n 12).

${ }^{16}$ Josef Raz, 'The Problem of Authority: Revisiting the Service Conception', (2006) 90, Minnesota Law Review, 1003 1044. In the next paragraphs, I will reconstruct the essential features of Raz's argument on authority.

${ }^{17} \operatorname{Raz}(\mathrm{n} 12)$.
} 
1) the normal justification condition: authority is legitimate if following its commands would induce the subject to better conform "to reasons that apply to him anyway" (besides the directives of the authority) than if he did not. ${ }^{18}$

2) the independence condition: the first requirement can be satisfied only if another condition is met; namely, that acting for the right reasons is more important than acting autonomously. I might, for instance, have a reason to conform to the law regarding the regulation of use of cars in public streets because not doing so would endanger both my life and the lives of others. In this case, my conforming to the authority of the law is better than my reasoning autonomously.

A binding authoritative directive for Raz is not only a reason to behave as it directs, but also an exclusionary reason; that is, a reason for not following the reasons that conflict with the rule. Legitimate laws and the directives of legitimate authorities pre-empt the background reasons that might militate against authoritative reasons and replace them with morally binding standards. Legitimate authority improves our conformity with reasons by overriding what we would do without it. Raz also asks whether consent is necessary for justifying legitimate authority. Some might argue that no obligation is valid without one's consent, but this seems an implausible account. For instance, respect for one's humanity, as Kant would have argued, is subjected to a preliminary duty rather than to consent. Consent does not solve the problem. Instead, it can be appealed to only when there is already a reason for such consent to be binding on us, namely, when legitimate authority impels us to conform to better reasons.

I will not discuss whether Raz succeeds in justifying authority as performing a service on the basis of an improved standard of reason. What I will argue instead is whether, once we concede to Raz that appeal to reason is a necessary step to justify authority, this also represents a sufficient claim. My view is that Raz's explanation requires two qualifications to be met: one external and providing an ontological justification of authority, and the other internal and connected to the types of reasons that legitimize the political exercise of authority. I will not address the issues raised by the first type of question (the ontological justification). I consider that in this case an argument can be provided in light of a practice in assigning roles. ${ }^{19}$ I pursue, instead, the idea that legitimate claims to authority should not violate a minimum threshold of reason - defined in terms of a cosmopolitan standard — such that any restriction of freedom should be justifiable.

Here is a possible account. Raz's "normal justification" thesis tells us what an authority order does, but it does not tell us what makes an order legitimate. It claims that if authority is justified, then it should deliver legitimate orders; however, since it might fail to do so, as when an

\footnotetext{
${ }^{18} \operatorname{Raz}(\mathrm{n} 14) 1014$.

${ }^{19}$ On this more radical criticism of Raz's theory issue see Scott Hershovitz, 'The Role of Authority', (2011) 11(7), Philosophers' Imprint, $11 \mathrm{ff}$.
} 
act is considered an "abuse" of authority, the threshold that authority should meet in delivering legitimate reasons needs to be singled out.

My point is that if authority is justified, according to a certain ontological thesis, then its commands are legitimate only in so far as they don't infringe on a cosmopolitan standard of reason: a duty to provide a justification. The argument I suggest appeals to an original condition of association - what Kant called an original communio fundi originaria. It is from this fictional scenario that a cosmopolitan duty to justification can be inferred. ${ }^{20}$ The argument from an original community for the shared use of earth would claim that any restriction of an original right to freedom is legitimate only in so far as it does not violate a concern of equal freedom among people. Such concern is subject to the circumstances of disagreement, namely, to the justification of authoritative decisions in the realm of conflicting claims.

In light of a cosmopolitan obligation, the original duty to justification represents an intersubjectivist standpoint incorporated within the law. ${ }^{21}$ The cosmopolitan duty to justification can indeed disclose a space of reasons for the justification of prescriptive norms of action — what in speech-act theory is referred to as the dimension of content validity of speech acts. ${ }^{22}$ The duty to cosmopolitan justification transforms the merely subjective character of motivations into a publicly justifiable domain of reasons. Nevertheless, as a product of a general duty to justification, such reasons do not demand validity in the same manner as the Habermasian ideal speech situation. . It is, indeed, not the case that compliance to a cosmopolitan duty to justification proceeds through the idealization of the conditions of acceptability of discourses (ideal conditions). On the contrary, it requires a more modest criterion of non-rejectability. Compliance to a cosmopolitan duty of authority, therefore, is satisfied in so far as it does not violate a general standard of non-rejectability.

Until now, I have referred to the content legitimacy aspect of the reasons advanced by claims of cosmopolitan authority. However, legitimacy concerns also raise the question of whether the subject advancing a certain claim is legitimate. Even granting the possibility that there is a plurality of ontologically justified subjects, is the particular subject advancing a certain claim truly entitled to make such a claim?

\footnotetext{
20 "The Communio originaria is not empirically grounded as factum or occurrence, but is a right to the land without which no human being can exist, and which itself follows from freedom in the use of things"; however, the right to a place on the land is "not a right to a thing but my innate right to freedom, which no one can take away from me", Paul Guyer, Kant on Freedom, Law and Happiness (Cambridge University Press 2000) 253. The quotation is from, Immanuel Kant, Vorarbeiten zur Rechtslehre, 23:241, 281.

${ }^{21}$ See Rainer Forst, 'The Justification of Human Rights and the Basic Right to Justification. A Reflexive Approach', in Claudio Corradetti (ed), Philosophical Dimensions of Human Rights. Some Contemporary Views (Springer 2012) 81106.

${ }^{22}$ See Forst (n 11) 56ff. I have defended a similar point in Claudio Corradetti, Relativism and Human Rights. A Theory of Pluralist Universalism, (Springer 2009) 95.
} 
This second aspect concerns the legitimate entitlement of those subjects who pretend to advance a claim of authority. In order to address point b) and with regards to the question of legitimacy, it should be observed that cosmopolitan authority provides a standard for the identification of legitimate authority in a condition of pluralism.

Both types of legitimacy are intertwined criteria. Indeed, whereas a procedural justification helps in identifying those legitimate subjects that have a title to the exercise of authority, a substantial justification defines patterns for the conceptualization of authority. Being a legitimate subject of authority does not relieve an institution from meeting demands of justification. Furthermore, to achieve such demands means for cosmopolitan authority to overrule outcomes generated solely by an individual exercise of moral autonomy. This appears to be connected to what some have identified as the major difficulty with regard to the Kantian view on moral autonomy: the problem of unencumbered moral self vs an intersubjective rationality.

Judicial cosmopolitan authority, as an authority to second order reasons for action, provides arguments that are both intersubjectively rational as well as normatively exclusivist with regard to a plurality of potentially competing prescriptive claims. The justification of authority, in this regard, furnishes improved conditions for rational deliberation. Any restriction of rights is held publicly accountable with respect to an ultimate cosmopolitan demand of authority. Cosmopolitan inclusion makes consistent the exclusivist character of authority with a plurality of prescriptive claims. Claims to justified authority guarantee a condition that would be otherwise unattainable from only a solipsistic standpoint. In overcoming individual moral claims, judicial cosmopolitan authority realizes an obligation to obey the authority of the law.

In order to illustrate this point, I reconstruct a standard of identification for legitimate authority and for authority-transferring which conceptualizes the cosmopolitan adoption of the subsidiarity principle in terms of a "reversed" use. This represents a criterion for the application of a notion of judicial cosmopolitan authority in a context of pluralism following from the notion of cosmopolitan obligations.

A complete account of judicial cosmopolitan authority therefore combines a substantive standard of legitimacy with a procedural identification of legitimate authority. In a regime of pluralism, exclusionary reasons for the exercise of judicial cosmopolitan authority are applicable by means of a reversed interpretation of a subsidiarity standard.

Alternative interpretations of authority to the one presented here have focused on the idea of "relative authority". ${ }^{23}$ They have claimed that states should "cooperate with, tolerate, or even

\footnotetext{
${ }^{23}$ Nicole Roughan, Authorities: Conflicts, Cooperation, and Transnational Legal Theory (Oxford University Press 2013).
} 
subject themselves to other authorities [...]". ${ }^{24}$ The concept of judicial cosmopolitan authority accepts such views favorably. Indeed, the principle of reverted subsidiarity is compatible with the notion of a plurality of prima facie legitimate claims to authority. Nevertheless, it considers that the relativity of authority is dissolved by means of a cosmopolitan standard. It follows that pluralism is not a conclusive concept, but rather one which is conducive to the justification of exclusivist authority on the basis of cosmopolitan reasons. This accounts for the definition of cosmopolitan constitutionalism as being both exclusivist and heterarchical - a point which I have introduced at the beginning when distinguishing between domestic and transnational constitutionalism.

To clarify this point, it is useful to distinguish between the exclusivist character of judicial exercises of cosmopolitan authority, as those emerging against a persistent pluralist background, and those theories that construct a notion of authority on either an account of exclusive monism or, alternatively, on a strategy of inclusive pluralism. While judicial cosmopolitan authority defends the view of authority in terms of a heterarchical and exclusivist character of legal prescriptions, the other two approaches combine hierarchy and exclusivity of prescriptions in one case, and heterarchy and inclusivity of prescriptions in the other. The notion of judicial cosmopolitan authority admits, therefore, a legitimate presumption in favor of a plurality of valid claims to authority. Nonetheless, such plurality surrenders to the exclusive authority of a cosmopolitan justification in conjunction with a reversed use of the subsidiarity standard. To the plurality of claims to authority, it follows that there is only one valid adjudicative output where the ultimacy of authority is decided in virtue of public arguments that comply with a general cosmopolitan obligation. ${ }^{25}$ This point connects to a final aspect, namely, to the effects of constitutionalization of international law. From the arguments provided thus far, these effects are the result of authoritative claims and their shaping of a basic (cosmopolitan) structure.

The third and final point - c) - concerns how judicial cosmopolitan authority reflects a "constitutional mindset" for reasoning about international law. It regards also how this provides an anti-fragmentation effect as something radically adversarial to a technocratic strategy. ${ }^{26}$

This is also a thesis defended by Kant. In Appendix I of Perpetual Peace Kant explains why there should be a connection between morality and politics if morality as such has to become a meaningful project for action. ${ }^{27} \mathrm{He}$ claims that if there were an irreconcilable conflict between theory and practice, between what we are commanded to do by the moral imperative and what we

\footnotetext{
${ }^{24}$ Roughan (n 20) 178.

${ }^{25}$ For a theory of "relative authority" centered on radical pluralism, see Roughan (n 20) 169.

${ }^{26} \mathrm{I}$ borrow this expression from, Martti Koskenniemi, 'Constitutionalism as a Mindset. Reflections on Kantian themes about international law and globalization' in Theoretical Inquiries in Law, (2006) (8)1, ISSN (Online) 1565-3404, 9-36.

${ }^{27}$ See Immanuel Kant, Perpetual Peace, Appendix I 'On the disagreement between morals and politics in relation to perpetual peace', in Hans S. Reiss (ed) Kant Political Writings (Cambridge University Press 2012 [1795]) 116-130.
} 
are in fact capable of doing in practice "this would be tantamount to denying that morality exists". ${ }^{28}$ For, if we could not act in accordance to moral demands, any use of politics would become a legitimate means for advancing expediency and self-interest. This point is synthesized, to my understanding in the Kantian maxim for which "ought" implies "can", namely, that the moral determinants of politics translate into freedom-enhancing laws. Consequently, on the basis of the accord between morality and politics a distinction is to be drawn between the role of the "moral politician, i.e. someone who conceives of the principles of political expediency in such a way that they can co-exist with morality" and that of a "political moralist, i.e. one who fashions his morality to suit his own advantage as a statesman". ${ }^{29}$

Whereas the moral politician sees in terms of a duty the subordination of political action and legal reforms to the mandates of morality, the political moralist disguises his personal advantage along moral terms and "under the pretext that human nature is incapable of attaining the good which reason prescribes as an idea". ${ }^{30}$ It follows that when the two strands are confronted with the question of how to construct the cosmopolitan project, the moral politician interprets this as a "moral task". Such accomplishment has to be realized through the expansion of the rule of law and the ordering of the sources of international law, namely, through the advancement of a "cosmopolitan constitution". 31

Differently from the moral politician, the political moralist sees the cosmopolitan project in terms of a "technical issue" and perpetual peace as simply a result of a "physical good" but not also of a lawful condition. ${ }^{32}$ According to the latter perspective, it is on the basis of states' interests and in view of a cost/benefit analysis that solutions to international problems are to be sought. Kant cannot accept this possibility and indeed in the concluding paragraphs of Appendix I of the Perpetual Peace, he declares that "the right should be sacred [heilig] to humans [dem Menschen] [emphasis added]" alluding to a non-technical interpretation of the significance of the law in view of its non-instrumental value. ${ }^{33}$

Constitutional thinking, thus, represents a method for practical reasoning — what we call nowadays global or transnational constitutionalism. It concerns the process of unification of public international law by means of compliance to a cosmopolitan ideal. As Kant states in the fourth thesis of the Idea: "[...] nature employs in order to bring about the development of all their

\footnotetext{
${ }^{28}$ Kant (n 24) 116.

${ }^{29}$ Kant (n 24) 118.

${ }^{30}$ Kant (n 24) 119.

${ }^{31}$ Immanuel Kant, 'Toward Perpetual Peace: a Philosophical Sketch', in Pauline Kleingeld (ed) Toward Perpetual Peace and Other Writings on Politics, Peace, and History (Yale University Press 2006, [1795]) 67, [8:358] 82.

${ }^{32}$ Kant (n 24) 122. On the cosmopolitan extension of this right see the contribution of M.Savino in this symposium.

${ }^{33}$ I depart here from the translation of Reiss (n 24) where he translates "das Recht dem Menschen" with "the rights of man".
} 
predispositions [...] their antagonism in society, insofar as the latter is in the end the cause of their lawful order". ${ }^{34}$ The unsocial sociability of men depicted here with the word "antagonism" requires domestication through the enforcement of valid laws. This process should occur not only among individuals per se and within domestic borders, but also among states whenever engaged in warfare or aggressive behavior (i.e. through colonization). This requires in turn that the realization of a cosmopolitan condition (weltbürgerlicher Zustand) is postulated as a condition whereby states' compliance to a global rule of law is based on the respect of the Kantian cosmopolitan "right to visit" as a specification of an original claim to societal inclusion "by virtue of common possession of the surface of the earth". ${ }^{35}$ It is following from this Kantian premise that I consider that the constitutional transformation of international law demands compliance to cosmopolitan obligations.

The fostering of cooperative interplay among states has to consider nowadays a more complex system of transnational institutions than those operating during Kant's time. ${ }^{36}$ Nevertheless, Kant's argument against the opportunity of a centralized global sovereign, matches the empirical condition of today's international law coupled with a context of legal dispersion and fragmentation of regimes. ${ }^{37}$ Here, conflicts of international legal norms such as those among treaty norms cannot be solved by recurrence to a fixation of a hierarchy of legal sources. Indeed, it is apparent that with the sole exception of the jus cogens there is no such a priori hierarchy which can be established in international law. ${ }^{38}$ Furthermore, in the absence of a fixed hierarchy of legal sources for international law, it follows a fundamental difficulty with regard to the processes through which customs and general principles of international law become recognized as binding standards. $^{39}$

The answer I have tried to articulate considers that sources of international law are transformed by Courts in to legal arguments on the base of both a formal commitment to a reversed subsidiarity principle as well as on the base of a substantive justification to cosmopolitan authority.

\footnotetext{
${ }^{34}$ Immanuel Kant 'Idea for a Universal History with a Cosmopolitan Aim', in Amèlie Oksenberg Rorty and James Schmidt (eds), Kant's Idea for a Universal History with a Cosmopolitan Aim. A Critical Guide (Cambridge University Press 2009 [1784]) 13, [8:20] 9-23.

${ }^{35}$ Kant (n 28), 8:358, 82.

${ }^{36}$ Kant mentions, among others, the case of a "permanent congress of states" as the states-general at The Hague which took place in the first half of the $18^{\text {th }}$ century. See Immanuel Kant, 'Metaphysics of Morals, Doctrine of Right', in Pauline Kleingeld (ed), Toward Perpetual Peace and Other Writings on Politics, Peace, and History (Yale University Press 2006, [1797]) §43-§62.

${ }^{36}$ Kant mentions, among others, the case of a "permanent congress of states" as the states-general at The Hague which took place in the first half of the $18^{\text {th }}$ century. See Immanuel Kant, 'Metaphysics of Morals, Doctrine of Right', in Pauline Kleingeld (ed), Toward Perpetual Peace and Other Writings on Politics, Peace, and History (Yale University Press 2006, [1797]) §43-§62.

${ }^{37}$ See Joost Pauwelyn, Conflict of Norms in Public International Law. How WTO Law Relates to other Rules of International Law (Cambridge University Press, 2003) 16 ff.

${ }^{38}$ See Pauwelyn (n 34) 89 ff.

${ }^{39}$ On these distinctions see Pauwelyn (n 34) $91 \mathrm{ff}$.
} 
Together, these two criteria define a tertiary level in international law, a level that defines a legitimate subject of authority on the base of a substantive argument.

Since there might be cases of conflict among regimes on the application of secondary rules with regard to who should be accounted as a legitimate subject for the interpretation of customary international law and treaty rules (as well as on how these rules should be accounted), the construction of a tertiary level appears as a necessary direction to take in order to the solve such tensions. ${ }^{40}$ In the absence of a predefined hierarchical legal structure, both secondary and tertiary rules contribute to the formation of one single cosmopolitan legal space for the allocation of legitimate authority. Here, the "cosmopolitan turn" of international and constitutional law accounts for what is a correlation between those who are the relevant subjects for the global legal community and for what are the justificatory strategies that are necessary to the realization of the cosmopolitan ideal. Variations occur with regard to which institutional subjects are mostly suited for the vindication of the cosmopolitan claims, even when the delegation of authority to supranational levels remains normatively bound to a process of judicial legitimation.

\section{§2 Judicial Claims to Cosmopolitan Authority: Trajectories in Global Constitutional} Moments

In this final section I illustrate the progression towards a cosmopolitan constitution understood along heterarchical and exclusivist lines as well as constructed upon selected practices of judicial authority.

There are at least three different areas through which it is possible to account for this process. The first level, that which illustrates the core of the idea of the cosmopolitan project, concerns the judicial interaction of courts whereby constitutional integration is the result of judicial claims to cosmopolitan authority. This core area receives support by two other levels of constitutional integration such as the role that judicial claims to authority perform in transjudicial dialogue and communication and which account for a constructivist approach to global legal principles. Finally, there is a minimum threshold which should be met within jurisdictions participating into the legal cosmopolitan project. This third level considers demands of sufficient standards of inclusion on the base of the so-called "transitional" jurisprudence of the ECtHR. Here a non-ideal process is at work

\footnotetext{
${ }^{40}$ The equation I defend here between the reversed interpretation of the subsidiarity principle as a tertiary level for the unity of international law represents an elaboration of Trachtman's notion of tertiary rules: "Implicit in this concept of' tertiary rules' is the non-exclusivity of constitutionalization. That is, it is possible to have multiple levels and locations at which constitutionalization takes place. The nation state holds no monopoly", in Joel Trachtman 'The Constitutions of the WTO' (2006) The European Journal of International Law 17 (3) 623, 627.
} 
for the constitutional advancement of not yet, or not fully democratized states. Let's begin with the case-law illustration of the core thesis of cosmopolitan authority.

In October 1999, the UN Security Council adopted Resolution 1267 establishing an embargo on Afghanistan as well as financial measures against Taliban assets. ${ }^{41}$ One year later, in the absence of compliance from the Taliban, the Council passed resolution 1333 which ordered the freezing of financial assets for individuals and groups associated with the Al-Qaida organization. ${ }^{42}$ The world of international relations and international law was changing and it indeed changed drastically after September 11 when on 28 September 2001 the Security Council passed resolution 1373, followed by Resolution 1390 in January 2002 which restricted several other freedoms. Distinct from the previous measures, Resolution 1390 aimed to be globally applicable and endowed with unlimited scope, as both territorially and temporally unconstrained. The result of the decision was that no state was allowed to let targeted persons enter their territory or use frozen financial assets. The Security Council did not require individuals to comply with a certain behavior as it normally did in previous cases with states. It simply ordered the suspension of certain fundamental freedoms to a blacklist of suspected terrorists. ${ }^{43}$

Did the Security Council clearly establish its own global power and agenda by declaring a state of exception? To some this appeared to have been the case. Since only states could represent themselves in front of the Security Council, individuals were deprived of a means of self-defense. Yet, the story that unfolded turned out to be unexpectedly and paradoxically entirely in favor of a strengthening of human rights protections. First in 2006, with Resolution 60/251, it was created the UN Human Rights Council. This institution allowed, among others, for an individual complaint procedure - Resolution 5/1 of 2007. As I argue, it is precisely at this moment that something more profound and systemic than just an institutional reform occurred, one which affected more in general the ideal of global constitutionalism.

I maintain indeed that as a reaction to the UN Security Council Resolutions relative to the "terror list" issued in response to the global threat of 9/11 a new global constitutional phase has followed. Indeed, it is not only the case that international law has been reshaped by an initial phase of "human security," 44 but also that this decision has been followed by a reaction of regional regimes, such as the ECHR and the EU. Here claims to judicial cosmopolitan authority, as I argue,

\footnotetext{
${ }^{41}$ SC Res. 1267, 15 October 1999.

${ }^{42}$ SC Res. 1333, 19 December 2000.

${ }^{43}$ Rule 37 of the Provisional Rules of Procedure of the Security Council (S/96/Rev.7, 1983). On this point see also Noah Birkhäuser, 'Sanctions of the Security Council against Individuals. Some Human Rights Problems, European Society of International Law' (2005), http://www.esil-sedi.eu/sites/default/files/Birkhauser.PDF (accessed on 14 November 2015).

${ }^{44}$ The notion of "human security" is constructed on the basis of a convergence of International Humanitarian Law, Criminal Law and Human Rights Law, see Ruti Teitel, Humanity's Law (Oxford University Press, 2011). See Isayeva v. Russia, Application No.57950/00, Judgment, ECtHR (2005).
} 
have prompted a progression in the direction of a more mature form of global constitutionalism. Judicial cosmopolitan authority in this respect has contributed to advancing standards of constitutionalization of international law and promoted a transnational rule of law.

Indeed, the problem prompted by the UN Security Council Resolutions on "terror list" the UN Security Council Resolution 1267 of 1999 and Resolution 1390 (2002) — was that the addressees of the measures had not been treated as moral ends. Even more importantly, they had not been considered as equal subjects of law. To illustrate this point it is worth considering the rationale of the Kadi case on which I will return more extensively later. ${ }^{45}$ In its final judgment the CJEU annulled Council Regulation (EC) No 881/2002 of 27 May 2002 and therefore the applicability of the aforementioned Security Council's (Sanctions Committee) Resolutions 1267 (1999) as well as those that followed. The Court considered that the measures foreseen by the Resolutions with regard to the freezing of funds and economic resources of the suspects did not meet human rights thresholds at a level equal to that protected in the European Community. The Security Council acted ultra vires when it requested state parties to intervene in the implementation of such measures. In particular, Mr. Kadi's right to be heard was infringed. The Court specified that the Sanctions Committee did not provide for a concrete possibility of removing one's name from the list by means of exercising her own rights to be heard. Indeed, this option was severed both by strictly diplomatic and intergovernmental procedures foreseen by the Committee, and by the veto right granted to each Committee member. Finally, the Committee was held under no obligation to provide a justification if it refused to remove a name from the list. The Court also considered that whereas it could have potentially been the case that Mr Kadi's right to property was legitimately restricted, lacking the possibility for defending himself before the competent authorities infringed his right to property.

In addition to the core case represented by the Kadi, judicial claims to cosmopolitan authority are incorporated also within other judicial practices. I will abstract in the present circumstances from assessing cases of domestic exercises of universal jurisdiction and focus, instead, on three main dimensions of judicial practices whereby cosmopolitan authority is grounded. These three areas include: A) standard claims to judicial cosmopolitan authority, as the one just introduced with the Kadi case B) claims to cosmopolitan authority through transjudicial dialogue, and C) judicial claims to minimum thresholds of cosmopolitan authority, as in the case of transitional justice adjudications.

The scheme below provides a more detailed description of the areas involved.

\section{A) Standard Claims to Judicial Cosmopolitan Authority}

\footnotetext{
${ }^{45}$ Kadi and Al Barakaat International Foundation v. Council and Commission [2008] ECR I-6351.
} 
This level is characterized by heterarchy of jurisdictions when asserting the ultimacy of cosmopolitan authority as with, respectively, the impact of national constitutional courts on regional organizations. This includes A1) states' cosmopolitan demands of EU compliance to national constitutional human rights standards (Solange Case), or demands of regional courts to either A2) as for instance with cosmopolitan claims of authority by the CJEU in its exercise of judicial review on resolutions by the UN Security Council (Kadi case), or with A2.1) claims to cosmopolitan authority by the ECtHR when criticizing states' implementations of UNSC resolutions conflicting with ECHR principles (Nada case).

B) Claims to Cosmopolitan Authority through Transjudicial Dialogue

This level focuses on transjudicial interaction through courts' cross-references on the base of judicial dialogue. It considers that judicial dialogue promotes the overlapping and strengthening of jurisprudence between judicial bodies among themselves or between judicial and non-judicial bodies, as with the convergence of the ECtHR and the Human Rights Committee (HRC).

C) Judicial Claims to Minimum Thresholds of Cosmopolitan Authority

Finally, it must be recognized a top-down exercise of judicial authority on state-parties where human rights standards are affirmed in transitional state-contexts. Influence by courts is realized on the base of the advancement of standards of democracy, as in the case of the "transitional jurisprudence" of the ECtHR, i.e. with the former Soviet Union states.

As I have anticipated, I consider in particular the case-law of A) as illustrating the core practices of cosmopolitan authority. Also, I take that cosmopolitan authority represents a novel interpretation for those same cases which have been previously understood in terms of "relative authority". ${ }^{46}$ The theory of judicial cosmopolitan authority that is here presented does not reject the notion of relative authority as such but it considers that it is instructive only in so far as it accounts for an intermediate approximation towards a cosmopolitan ideal. Therefore, cosmopolitan authority claims that in each given case an exclusive exercise of judicial cosmopolitan authority follows from relative exercises of authority. Both are instances of one "single phenomenon" which spans from a more to a "less interactive process of intellectual cross-fertilization". ${ }^{47}$ This explains also more

\footnotetext{
${ }^{46}$ For this position see Roughan (n 20) $204 \mathrm{ff}$.

${ }^{47}$ Anne Marie Slaughter, ‘A Typology of Transjudicial Communication' (1994) 29 (99) University of Richmond Law Review, 101.
} 
precisely what is the role performed by judicial dialogue and transitional justice adjudications in approximating the ideal of cosmopolitan authority by means of a preliminary conceptualization of relative authority. Indeed, judicial dialogue through cross-references contributes to signal an overlap and a strengthening over cosmopolitan legal principles upon which judicial claims to cosmopolitan authority are constructed. In its turn, transitional justice adjudications advance a topdown judicial demands on states' democratic membership for cosmopolitan authority. Finally I show cases A.1-2.1 demonstrate how legitimate demands of cosmopolitan authority are grounded on arguments of systemic unity of international law. These latter thresholds provide an account for the connection between claims to cosmopolitan authority and constitutional effects on international law. In the following sections, I discuss the connection between these three judicial mechanisms.

\section{A) Judicial Claims to Cosmopolitan Authority and the Constitutionalization of International Law}

The cases I present hereafter illustrate how practices of judicial cosmopolitan authority contrast the potential fragmentation of international law by prompting a yet more mature phase of constitutional advancement. These phenomena also elucidate how it occurs a dual-interaction or even three-structured interaction among regimes. The examples presented below illustrate also a constitutional trajectory for international law. ${ }^{48}$

To start with, I refer to what I have already introduced and show how certain instances of judicial reasoning reveal a pattern grounded on a "reverse" endorsement of the subsidiarity principle - a heuristic principle for defining the cosmopolitan scope of judicial competence. ${ }^{49}$ The reverted adoption of the subsidiarity principle exemplifies the criteria for the legitimate transferring of cosmopolitan authority on the basis of the assumption that the outreach of adjudication is the widest, unless otherwise proved. This is a principle of selection for the most adequate level of adjudication with regard to consideration of the regulative standard of non-rejectability by "allsubjectable" people. What is distinctive of this idea is that a cosmopolitan regulative standard is maintained also at the lower levels, that is, where reasons of efficiency favor lower level

\footnotetext{
${ }^{48}$ On the relation between the mandates of UN-related criminal courts and the progressive construction of piecemeal of cosmopolitan justice, see the contribution by Zyberi in this symposium.

${ }^{49}$ I adopt this concept from Julianne Kokott and Cristoph Sobotta 'The Kadi Case - Constitutional Core Values and International Law - Finding the Balance?' (2012) 23(4), The European Journal of International Law 1015,1024 and apply systemically to systems integration. On the discussion of the principle of subsidiarity as a constitutional principle and on its "need of substantive interpretation" as well as the need to rethink state centrality, see Andreas Føllesdal, "The principle of subsidiarity as a constitutional principle in international law' (2013) 2 (1) Global Constitutionalism 37, 39 ff.
} 
constituency-solutions. ${ }^{50}$ One clear illustration comes from the Solange. ${ }^{51}$ In Solange I, the German Constitutional Court (GCC) considered that the level of protection of human rights at the EU level was lower than the national. It therefore decided to review EU law "As long as the integration process has not progressed so far that Community law receives a catalogue of fundamental rights [...]". 52 This understanding changed with Solange II. Here the GCC declared that there was no need to review EU standards of human rights, since their level of protection had increased substantively in the meantime. In this second case, the GCC suspended its review "so long as" ("so lange" in German) the EU continued to grant protection of fundamental rights at the same standard as the German domestic level. ${ }^{53}$ One interesting point here concerns the definition of the standard adopted by the court in justifying its decision to waive adjudicative powers. There are two interdependent criteria motivating adjudicative transfer on the basis of a reversed subsidiarity standard: a) the cosmopolitan doctrine of equivalent protection, and b) the clause on sovereignty claim. In both cases, it should be noticed that while "an inalienable core" of state's sovereignty remains uncompromised, cosmopolitan adjudication is delegated through the transferring of legitimate authority. ${ }^{54}$ Even if in Solange II the German Constitutional Court decided to suspend the exercise of its jurisdiction for "secondary Community law", it never aimed to modify the unity of the constitutional order. ${ }^{55}$ This means that no compromise was sought on the sovereign indivisibility of the state, namely, that the claim to sovereign autonomy by the court did not become a delegated power.

Moving to the transnational level, as already introduced, a case which illustrate the core judicial practice of cosmopolitan authority is the already mentioned Kadi case. Here the CJEU reviewed the judgment of the Court of First Instance (CFI) and refused to apply within the EU a

\footnotetext{
${ }^{50}$ I elaborate the "all-subjectable" along regulative lines in response to the criticisms and formulations by Sofia Näsström and Nancy Fraser to the widely used "all-subjected" principle in contemporary scholarship. See Sofia Näsström 'The Challenge of the All-Affected Principle' (2011) 59 (1) Political Studies, 116-134. See also Nancy Fraser Scales of Justice: Reimagining Political Space in a Globalizing World (Polity Press 2008), 56 ff. My interpretation is that the question on who should be included as a subject of justice (the "who question") is answered by the consideration of whom are the addressees of the norms of a governance structure ("whom question" as I consider it). This requires that individuals are recognized as both subjects and addressees of the law. In this respect, I provide an extended understanding of Dahl's version of the demos that he defines in terms of the "all-subjected principle" and whereby he excludes "transients, and persons proved to be mentally defective" Robert Dahl, Democracy and its Critics (Yale University Press 1989), 120-9, cited in Sofia Näsström (n 46) 119. The problem with Dahl's notion is that it overlooks the fact that, more often than not, the subjects he excludes are precisely those who are most entitled to have a say in the terms of acceptability, and thus subjectability, of a certain legal measure.

${ }^{51}$ It must be said that before this case, it was the Italian Constitutional Court that in 1965 recognized the conditions informing the international transference of state's powers as subjected to an equivalent respect of human rights, see Corte Cost., 16 December 1965, n.98.

${ }^{52}$ BVerfGE 37, 271 [1974] (Solange I).

${ }_{54}^{53}$ BVerfGE 73, 339 [1986] (Solange II).

${ }^{54}$ See, for instance, Guglielmo Verdirame 'A Normative Theory of Sovereignty Transfers' (2013) 49 (2) Stanford Journal of International Law, 374.

${ }^{55}$ Bundesverfassungsgericht [BVerfG] [Federal Constitutional Court] Oct.22, 1986, BverfGE 73, 339; Case No.2 BvR 197/83, 93 ILR 403, 433, 436 (known as Solange II).
} 
UNSC resolution restricting rights for persons allegedly connected to Al-Qaeda and the Taliban (UNSC resolution 1267, 1999). Whereas the CFI claimed that the UNSC did not breach any principle of jus cogens, the CJEU rejected its applicability "in the light of the fundamental rights forming an integral part of the general principles of Community law [...]". ${ }^{56}$ In this way, Mr Kadi's request of annulment based on the infringement of the right to property, the right to be heard and the right to effective judicial review was received by the Court. As clearly emerged from the statement of Advocate General Maduro: "international law can permeate that [Community] legal order only under the conditions set by the constitutional principles of the Community". ${ }^{57}$ Also, in this case, the primacy of higher order systems has been considered to be dependent on the maintenance of standards of human rights accountability otherwise triggering a review procedure by lower-ranking legal systems. ${ }^{58}$ The claim to cosmopolitan authority by the CJEU represents a further level of bottom-up constitutionalization of international law through the fulfillment of human rights standards. In this case, as with the cases presented before, the general presumption of a formal unity of international law is based on a "reversed" understanding of the subsidiarity principle.

A final illustration for reconstructing this transnational constitutional trajectory concerns the application of a UNSC resolution by an ECHR member, as in the so-called Nada Case. ${ }^{59}$ Here, the ECtHR requested Switzerland to provide an alternative interpretation of the UNSC resolution compatible with the ECHR. Mr. Nada, an Egyptian-Italian citizen was added to the list of the Sanctions Committee by the UNSC and subjected to its restrictions, particularly with prevention from entry or transit in the Swiss territory (Security Council resolution 1267, 1999). The problem was that Mr. Nada resided in Campione d'Italia, a small town surrounded on one side by the Italian Canton, and on the other side by the Lake of Lugano. As a result of implementation of the UNSC resolution 1333 issued in 2000 (expanding the security measures of resolution 1267, 1999), the Swiss Government added a new article prohibiting entrance or transit through Switzerland. It followed that Mr. Nada remained locked in Campione d'Italia for several years.

In 2008, Mr. Nada lodged an application against Switzerland for an alleged breach of right to liberty (Article 5 of the Convention), right to respect for private and family life (Article 8), and ill-treatment (Article 3). In addition, he claimed that there was a breach of his freedom to manifest

\footnotetext{
${ }^{56}$ Case C-402/05 P and C-415/05, Kadi and Al Barakaat International Foundation v. Council and Commission [2008] ECR I-6351(para. 326).

${ }^{57}$ Opinion of Advocate General Maduro, Kadi, 3 C.M.L.R. 41 (2008).

${ }^{58}$ That this selection of cases is reflects an autonomously justified normative theory is evident, among other things, from the fact that I don't consider as a relevant illustration the case of Al-Jedda. Here, as the ECtHR found that the House of Lords did not have ground to claim that the Security Council Resolution 1546 implies a breach of human rights so that a suspected individual could be kept under "indefinite detention without charge" (Al-Jedda v. The United Kingdom, [2011], 27021/08, 109, 2011).

${ }^{59}$ Nada v. Switzerland, [2012], 10593/08.
} 
his religion or beliefs since he could not leave Campione d'Italia to reach the nearest mosque (Article 9). Finally, he claimed that no effective remedy was sought for his complaints (Article 13). While the Swiss Government held that it was bound to implement the obligations under the UNSC resolution 1390 in virtue of art.103 of the UN Charter, the ECtHR held contrariwise that Switzerland had enough leeway to accommodate the UNSC resolution within the articles of the ECHR, as for instance, by urging Italy to request the removal of Mr. Nada from the "terrorist list" etc. The Court concluded that Switzerland breached art.8 of the Convention. The Court also held that "the respondent Government [had] failed to harmonize the obligations that they regarded as divergent," and that it could not have validly confined "itself on the binding nature of the Security Council resolutions". 60

It is questionable whether the respondent state had in reality a margin of manoeuvre for the implementation of the UNSC resolution. Indeed, a concurrent opinion of judges Bratza, Nicolau and Yudkivska highlighted the difference between the case of Al-Jedda, ${ }^{61}$ in which the UNSC did not specify any measure contrary to the Convention, and the UN resolution concerning Mr. Nada, where restrictions on movement where explicitly made. For the present purposes, it is interesting to highlight the Court's ratio in justifying the necessity for Switzerland to respect both art. 103 of the UN Charter and its obligations under the ECHR. The Court claimed that its findings dispensed from "determining the question, raised by the respondent and intervening Governments, of the hierarchy between the obligations of the state-parties to the Convention under that instrument, on the one hand, and those arising from the United Nations Charter, on the other. In the Court's view [...] the respondent Governments have failed [...] to harmonise the obligations that they regarded as divergent". 62

Finally, to the purpose of reconstructing the type of judicial reasoning grounding transnational principles of judicial claims to cosmopolitan authority, it is also worth considering that in the Nada Case, particularly in the concurrent opinion of Judge Malinverni, the Court should have acted more forcefully in seeking application of human rights directly for a UNSC resolution. In this respect, a parallel is drawn to the Kadi and to the review applied by the CJEU to the UNSC resolution. For Judge Malinverni this same rationale should have also been adopted in Nada. Indeed, as Malinverni emphasized, pre-eminence assigned by Article 103 refers to "the obligations ... under the present Charter" so that "[it is] appropriate to draw a distinction between the Charter itself, as the primary legislation of the United Nations, and the UNSC resolutions, binding (Article 25)" where the latter "may be regarded more as secondary or subordinate UN legislation". The

\footnotetext{
${ }^{60}$ Nada v. Switzerland , [2012], 10593/08, para.197, p.53.

${ }^{61}$ Al-Jedda v. The United Kingdom, [2011], 27021/08.

${ }^{62}$ Nada v. Switzerland, [2012], 10593/08, para.197, p.55.
} 
conclusion, for judge Malinverni, was that hierarchy in international agreements should be seen "in relative terms" specifically when an international human rights treaty is at stake. ${ }^{63}$ Notwithstanding differences, in all cases mentioned, an over simplistic notion of hierarchies of international institutions matched by an ultimate and overarching international law source should rejected. What does count seems rather that the kind of legal arguments that can most reasonably adjudicate for the legitimacy of cosmopolitan claims to authority should be assessed in the light of a pluralist scenario. Indeed, bringing Judge Malinverni's reasoning to its most appropriate conclusion, in the absence of a de facto institutional hierarchy, the preeminence of sources set by article 103 of the UN Charter is subjected to a de jure subordination of any UNSC resolution to a claim of non-rejectability, and this should be done in light of a cosmopolitan standard wherein the resolution applies. Seen as elements of one single constitutional trajectory, the Solange, the Kadi and the Nada, define together the parameters of possible claims of authority along a transnational cosmopolitan trajectory. Such claims do not surrender to arbitrary measures of security threats whenever these are inadequately justified. On the contrary these examples indicate that Courts, by the challenging the view of an interpretive hierarchy of the sources of authority, reshape along "cosmopolitan moments" the constitutional physiognomy of international law.

This bears important implications. Indeed, since it is the case that the "choice of the frame determine(s) the decision", as Koskenniemi has noticed, it is also the case that international law nowadays possesses resources for the definition of a "meta-regime, directive or rule". ${ }^{64}$ The judicial examples I have introduced with regard to the UN Security Council Resolutions "terrorist list" show precisely this trend. They show that human rights adjudications and regimes are developing "tertiary" rules for the allocation of legitimate authority. This represents a distinct moment the effects of which consolidate principles of transnational constitutionalism.

B) Cosmopolitan Authority and Transjudicial Dialogue

Courts cite each other and even when they do not do so directly, they acknowledge each other's works. For instance, the citation of the ECtHR jurisprudence by the U.S. Supreme Court with regard to the "European traditions", as in Lawrence v. Texas, is just one of several examples of cross citation, even when influence is exercised indirectly. ${ }^{65}$ Yet, as a phenomenon, cross-citation

\footnotetext{
${ }^{63}$ Concurrent Opinion of Judge Malinverni in Nada v. Switzerland , [2012], 10593/08, IV. 21, p.76.

${ }^{64}$ Martti Koskenniemi 'The Fate of Public International Law: between Technique and Politics' (2007) 70 (1) The Modern Law Review 1, 4.

${ }^{65}$ Lawrence v. Texas, 123 S. Ct.2472, 2481, 2483 (2003).
} 
reflects courts' self-perception as members of a globally shared judicial space. Transjudicial dialogue, I submit, represents a method for the construction of transnational principles of constitutional law. Judicial dialogue takes place outside a domain regulated by a treaty. For this reason, courts can bridge more freely remote legal domains in a constructively oriented manner. ${ }^{66}$ However, despite what the term suggests, this is not a cooperative enterprise as it appears more as a "monologue" than a dialogue. Cross citation does not, in fact, activate judicial interaction or responses. It represents, instead, single and unrelated events. Nevertheless, from the perspective of the practice of judicial claims to cosmopolitan authority, the expression "judicial dialogue" remains significant particularly when it assumes a global auditorium of judicial entities whose rejoinders span across time. It is in this wider understanding that the "constructivist function" of transnational constitutionalism serves the purpose of justifying judicial claims to cosmopolitan authority.

Such function is articulated along the following strands: a) as reinforcement of already existing principles of transnational constitutionalism when cross-citation is adopted to reinforce already existing standards, and b) as a construction of new principles furthering legal interpretation.

One example of the first case is Folger $\phi$ and others $v$ Norway where the ECtHR found a violation of Art. 2 of Prot.1 whereby the only partial dispensation of pupils from Christian teaching at a Norwegian primary school under the revised KRL curriculum endangered parents' private lives with the result of deterrence from the request. ${ }^{67}$ This reasoning reflected the same pattern of argumentation as that followed by the HRC. An even more striking case where the ECtHR explicitly adopted the reasoning of the HRC case law is that of Py $\mathrm{v}$ France with regard to conditions of residency for foreign citizens for participation in political elections in New Caledonia. ${ }^{68}$ Here, the Strasbourg Court held that New Caledonia was currently in a transitional post-colonial phase and that it was therefore justified in allowing participation in the selfdetermination process of sovereignty only to those persons showing historical ties with the territory. ${ }^{69}$

C) The "Transitional Jurisprudence" of the ECtHR

\footnotetext{
${ }^{66}$ This point implies a different classification than in Slaughter ( $\left.\mathrm{n} 44\right), 106 \mathrm{ff}$.

${ }^{67}$ See Folgerø and others v Norway (App no 15472/02). KRL is the acronym for "kristendomskunnskap med religionsog livssynsorientering".

${ }^{68}$ Py v France (App No 66289/01).

${ }^{69}$ See Magdalena Forowicz, The reception of International Law in the European Court of Human Rights (Oxford University Press 2010), 163.
} 
The European Convention of Human Rights sets the conditions for political inclusion as well as exclusion for those states seeking, respectively, democratic progressions vs return to despotic regimes. ${ }^{70}$ As a consequence of regime shifts, states engage in different forms of democratization that require a particular balancing and often human rights restrictions. In view of the mapping of relevant practices for judicial claims of cosmopolitan authority, the achievement of standards of acceptability of human rights protections, rule of law and democracy constitutes a prerequisite for the legitimacy of claims to authority. One challenging area where the transitional interpretation of human rights is at work concerns cases of party dissolutions informed by the adoption of the principle of "militant democracy". In those cases, the transitional jurisprudence of the ECtHR seeks to prevent weak or newly established democracies from turning into illiberal regimes. The principle of "militant democracy" was originally proposed by Karl Loewenstein in two consecutive essays published in $1937 .^{71}$ There the author claimed that in those cases where democracy "has not yet fulfilled its destination, it must fight on its own plane a technique which serves only the purpose of power. Democracy must become militant". ${ }^{72}$ The principle was adopted mainly in the context of post-Nazi fascist countries like Germany and Italy, and subsequently borrowed more recently also by the ECtHR.

In these cases examined by the Strasbourg Court, transitional jurisprudence has focused primarily on states once part of the Soviet Union, such as the Baltic states. ${ }^{73}$ In all these instances, state integration into the regime of the European Convention has proceeded on the basis of the ECtHR acting as a Court of last instance for the balancing of political freedoms and the preservation of democratic stability. This has raised the question of whether the Court has compromised the same universality of human rights particularly for those instances where a margin of appreciation has been granted in view of the restriction of fundamental rights. ${ }^{74}$ In addition, the Strasbourg Court considers the role that the notion of "passage of time" plays in the lowering of the risks of undemocratic turns and on this same basis it grants a margin of appreciation. As for the fulfillment of a standard of the rule of law, when rights-restrictive measures interfere with the Convention, the respondent state must show that it is acting in compliance with the law; whereas, as for the respect of the legitimacy standard, it is not enough to say that a measure by the contracting state has been

\footnotetext{
${ }^{70}$ See Michael Hamilton, 'Transition, political loyalties and the order of the state', in Antoine Buyse and Michael Hamilton (eds), Transitional Jurisprudence and the ECHR. Justice, Politics and Rights (Cambridge University Press 2011) 151-184.

${ }^{71}$ Karl Loewenstein, 'Militant Democracy and Fundamental Rights' (1937) 31(I) American Political Science Review, 417-432 and Karl Loewenstein, 'Militant Democracy and Fundamental Rights' (1937) 31(II) American Political Science Review, 638-658.

${ }^{72}$ Loewenstein (n 67, I) 423.

${ }^{73}$ For some of the cases concerning former Soviet Union states, see for instance Zdanoka v. Latvia 58278/00.

${ }^{74}$ See James Sweeney, The European Court of Human Rights in the Post-Cold War Era: Universality in Transition (Routledge 2013).
} 
imposed by the transitional context. Instead, it must be shown that the measure was compliant with the achievements of the general legitimate goals of the Convention.

Finally, for what concerns the standard of necessity, the Court values whether the adopted measure is necessary to perform the transitional task. In all these cases the key point is that the state is acting in accordance with a purpose of democratic consolidation, either on the basis of the rule of law, and/or in view of a standard of legitimacy and necessity. ${ }^{75}$ As noticed, a legal and philosophically relevant question is whether the Court, by granting a margin of appreciation for transitional contexts, compromises the same universality of human rights. In response to this anxiety, it must be recognized that the Court cannot compromise human rights standards by deferring to de facto circumstances of its transitional contracting parties. This indeed would vitiate the normative thinking to which the reasoning of the Court is bound. The understanding of human rights should instead proceed in an inherently contextual manner as with the use by the Court of a proportionality principle in the assessment of a standard of "reasonability" in state's arguments. It can be argued, therefore, that the Court is not meant to surrender to a form of relativism when dealing with cases of transitional justice. On the contrary it remains capable of endorsing a doctrine "of ethical de-centralization or subsidiarity". ${ }^{76}$

\section{Conclusion}

Throughout this essay, I have defended a notion of judicial cosmopolitan authority with reference to both a legitimacy standard and a standard of justification. In addition, I have advanced the possibility to propose a newly emerging grammar of transnational constitutional theory by means of illustration to relevant judicial practices. Despite their intentions, the UN Security Council Resolutions on terrorist threats have opened to a cosmopolitan understanding of constitutionalism "from within [a] new epistemic framework". ${ }^{77}$ Paradigm innovations in constitutional theory are connected to epistemic frameworks of social change as well as to the formulation, at the normative level, of yet new ideals of freedom. The idea of judicial cosmopolitan authority indicates the emergence of an unexplored discourse on transnational judicial constitutionalism, but this appears a normatively uncompleted view if left outside a pluralist understanding to claims of legitimate authority.

\footnotetext{
${ }^{75}$ On the analysis of the transitional jurisprudence of the ECtHR see Sweeney ( $\mathrm{n} 70$ ).

${ }^{76}$ See James Sweeney, 'Margins of Appreciation: Cultural Relativity and the European Court of Human Rights in the Post-Cold War Era' (2005) 54 International and Comparative Law Quarterly 459, 467.

${ }^{77}$ Hauke Brunkhorst, Critical Theory of Legal Revolutions (Bloomsbury 2014) 95.
} 
Indeed, differently from the fixed hierarchical structure of the liberal state model, the transnational arena remains to be governed in the absence of a single world Leviathan. Here the freedoms of the bourgeois, once safeguarded by the constitutional framework, are spread along a multiplicity of functionally differentiated arenas. The cosmopolitan citizen can only illusorily pretend to the same constitutional unity as that once guaranteed by the state. She is rather left to seek her own emancipation across a variety of specialized regimes, often operating in the maximization of outcomes dissociated from a regulative value system. ${ }^{78}$ What we are facing today with the inadequacies showed by the Westphalian model, were already apparent seeds of Kant's "transitional" understanding of the cosmopolitan law. ${ }^{79}$ The contemporary transformation of sovereignty certainly accepts the consideration according to which the transnational is characterized by an atomized conception of constitutional powers each claiming a judicial cosmopolitan authority for itself. Decidedly, the partial transference of a state's adjudicative powers complements the contemporary advancement of what Kant had already prefigured with the relaxation of the indivisibility of sovereign power. The reconstruction of judicial practices that I have presented here provides, therefore, only the inception of yet another cosmopolitan moment - what constitutional theorists call "ratchet effects".

Even though these instances are only a few among the examples that illustrate the exercise of judicial claims to cosmopolitan authority, they nevertheless grant leeway to ever-expanding possibilities as with the potential inclusion of non-Western forms of judicial cosmopolitan authority. The tracing of a plurality of roots for other judicial patterns represents, therefore, a desirable development for an even more comprehensive understanding of judicial claims to cosmopolitan authority. Nevertheless, any further non-ethnocentric expansion of the concept will confront itself with Hegel's dictum for which philosophical understanding arrives as it does with Minerva's owl only "when the shadows of night are gathering". ${ }^{80}$ Doubtless, the world of international law has already turned the page.

\footnotetext{
${ }^{78}$ With reference to Leibniz, Mario Prost suggests to consider the unity of international law in terms of "monads". If compared to the view advanced here, monadological unity implies the view according to which each $\mathrm{monad} / \mathrm{constitutional} \mathrm{regime} \mathrm{constructed} \mathrm{around} \mathrm{the} \mathrm{adjudicatory} \mathrm{powers} \mathrm{of} \mathrm{courts} \mathrm{differs} \mathrm{one} \mathrm{from} \mathrm{the} \mathrm{other} \mathrm{in} \mathrm{so} \mathrm{far} \mathrm{as}$ interpretations of international law are publicly justifiable in light of regional conventions and local contexts of adjudication. In Mario Prost, The Concept of Unity in Public International Law (Hart 2012), 21-22.

79 Jean Bodin, On Sovereignty, in Julian H.Franklin (ed), (Cambridge 1992). For a "transitional" reading of Kant, see Claudio Corradetti, 'Kant's Legacy and the Idea of a "Transitional' Jus Cosmopoliticum"' (2016) 29 (1) Ratio Juris.

${ }^{80}$ Georg Wilhelm Friedrich Hegel, Elements of the Philosophy of Right, in Barry Nisbet (trans), (Cambridge University Press, [1821] 1991), 23.
} 